\title{
Quantitative Analysis of Polyphenols and Biological Activity of Sage Macerates
}

\author{
GABRIELA STANCIU ${ }^{1}$, SIMONA LUPSOR ${ }^{1 *}$, FLORIN AONOFRIESEI², NICOLETA CALOTA ${ }^{3}$, ANTOANELA POPESCU4, \\ RODICA SIRBU 4 \\ ${ }^{1}$ Ovidius University of Constanta, Department of Chemistry and Chemical Engineering, 1 Universitatii Alley, 900470, Constanta, \\ Romania \\ ${ }^{2}$ Ovidius University of Constanta, Faculty of Natural Sciences and Agricultural Sciences 1, Department of Natural Sciences, \\ University Str. 900470, Constanta, Romania \\ ${ }^{3}$ Ovidius University of Constanta, Faculty of Physical Education and Sport, Physical Therapy Department, 124 Mamaia Blvd., \\ 900527, Constanta, Romania \\ ${ }^{4}$ Ovidius University of Constanta, Department of Pharmaceutical Science, 6 Capitan Aviator Alexandru Serbanescu, Constanta, \\ Romania
}

\begin{abstract}
The total phenols concentration in two sage macerates has been estimated by Folin-Ciocâlteau method, identified and quantified using HPLC-DAD method in order to assess the biological activity. The results for total phenols values of Folin Ciocalteau method indicate that Salvia officinalis L macerate S2, presents a higher amount of phenolic compounds than macerate S1. By HPLC-DAD method, six individual phenolic compounds were identified in sage macerates among which where cinnamic acid was found in highest concentration (652.478 mg/100g d.w. in S2 and $473.381 \mathrm{mg} / 100 \mathrm{~g} \mathrm{d.w}$. in S1). The antioxidant activity of sage macerates was evaluated using DPPH Radical Scavenging test. Sage macerates exhibited high antioxidant activity, between $439.5 \mathrm{mg} \mathrm{GAE} / \mathrm{mL}$ and $400 \mathrm{mg} \mathrm{GAE} / \mathrm{mL}$. Antibacterial activity of sage macerates was evaluated against $20 \mathrm{Gram}$ positive and Gram negative bacterial strains isolated from clinical specimens. Both macerates showed significant but variable antibacterial activity with inhibition zones ranging from $4.97 \mathrm{~mm}$ (S2) to 7.28. $\mathrm{mm}$ (S1). The effect was stronger on Gram positive (Enterococcus, Staphyococcus) than Gram negative bacteria (Escherichia sp, Proteus sp, Klebsiella sp). Eleven metals concentrations were determined by AAS method in sage leaves; it has been found that $\mathrm{Cd}$, Ni and $\mathrm{Pb}$ concentrations are below the detection limits.
\end{abstract}

Keywords: sage macerates, phenolic compounds, antioxidant activity, antibacterial activity, metals concentration

Salvia species are well-known for their useful properties since ancient times. They contain bioactive components with a wide range of applications, especially due to their antimicrobial properties [1].

In traditional medicine, it has been used for the treatment of different kinds of disorders including dyspepsia (such as heartburn and bloating), seizure, ulcers, gout, rheumatism, inflammation, dizziness, tremor, diarrhea, hyperglycemia, excessive sweating, atherosclerosis and inflammations in the throat and skin [2-4].

Sage macerates optimizes the reduction of inflammation and the reduction of edema in the ankle sprain (post immobilization period) allowing easier treatment of the affected joint by kinetotherapy procedures $[5,6]$.

Sage has beneficial effects in other conditions such as Parkinson's disease and ankylosing spondylitis [2].

For cosmetic purpose sage is used as tonic, cleansing agent, antidandruff, antioxidant, antiperspirant, deodorant, skin protector, astringent, antimicrobial, skin conditioning, etc. [7].

Despite of all the progress achived in synthetic drug research, plants and their products are still considered a valuble and major sources of remedies and have an extensive use in the pharma-industry $[7,8]$.

Studies show that Salvia officinalis L. contains a wide range of constituents including: alkaloids, carbohydrates, fatty acids, glycosidic derivatives, phenolic compounds, poly acetylenes, steroids, terpenes/terpenoids and waxes $[9,10]$.

Alcoholic and aqueous macerates of $S$. officinalis are rich in flavonoids [10], while rosmarinic acid and ellagic acid are the most abundant [11].
Comparative studies showed that the polyphenolic compounds from sage presents significant variations depending of the plant origin, extraction solvent and harvesting season [12].

Considering the data from scientific literature the following determinations using two samples of $S$. officinalis macerates (S1, S2) have been performed: i) the determination of the total polyphenolic content using the Folin-Ciocalteau spectrophotometric method, ii) the identification and quantification of the main phenolic compounds using HPLC-DAD method, iii) the evaluation of the antioxidant capacity using DPPH Radical Scavenging test.

The resistance of many pathogens to available antibiotics has become a global problem and stimulated the interest in natural alternatives. Therefore, the study of the antimicrobial properties and determination of the chemical constituents responsible for the biological effects of various plant components has become a priority [1316] to find new solutions in controlling pathogens and preventing infectious diseases and also in exploring a natural valuable source of antioxidants. In this context, the paper analyses the effect of sage macerates (S1, S2) against 20 bacterial strains isolated from clinical specimens.

Since the plants can accumulate some toxic compounds [17-20], sage leaves were tested to estimate the toxic metal concentration before the extraction. On the other hand, the content of other bioelements such as calcium, potassium, sodium, copper and zinc has also been evaluated. 


\section{Experimental part \\ Plant materials}

Leaves of Salvia officinalis L. were collected in June 2018 from organic culture in Topraisar, Constanta County, Romania. The leaves were dried at ambient temperature until constant weight was achieved and grinded to obtain powder.

\section{Chemicals}

All used reagents for chemical determinations were of analytical reagent grade.

Gallic acid was purchased from Fluka (Buchs, Switzerland) and Folin-Ciocalteau reagent from Merck (Darmstadt, Germany). The solution of gallic acid (standard phenolic compound) $1 \times 10^{-2} \mathrm{~mol} \times \mathrm{L}^{-1}$ was prepared by dissolving $0.1881 \mathrm{~g}$ of gallic acid in $100 \mathrm{~mL}$ ethanol. FolinCiocalteau reagent was diluted with distilled water 1: 2 (V:V).

DPPH (2,2-difenil-1-picrililhidrazil) was purchased from Aldrich (Germany). The standard compound solution $0.0063 \%$ ( $1.268 \mathrm{mM})$ was prepared in a $200 \mathrm{~mL}$ calibrated flask by dissolving $0.0010 \mathrm{~g}$ of 2,2-difenil-1-picrililhidrazil in methanol.

\section{Apparatus}

The chromatographic determinations of phenolic compounds were performed with HPLC-DAD system Agilent 1200, with quaternary pump, DAD, auto sampler.

Spectrometric measurements were carried out using a UV-Vis JASCO V550 scanning spectrophotometer.

Metals concentration determinations by AAS were done using a ContrAA ${ }^{\circledR} 700$ spectrometer. A Certipure multielement standard solution from Merck $(1 \mathrm{mg} / \mathrm{mL}$ of each metal) was used for calibration.

\section{Sample macerates}

The ethanol 970, used for maceration operations, was obtained by fermentation of grains.

The hydro-alcoholic macerate of Salvia officinalis L S1 has been obtained by maceration of $50 \mathrm{~g}$ powder of dry sage leaves with $200 \mathrm{~mL}$ ethanol $97^{\circ}$ for 3 months.

In case of $52,50 \mathrm{~g}$ powder of dry sage leaves was macerated for 3 months with $200 \mathrm{~mL}$ ethanol $97^{\circ}$ and 300 $\mathrm{mL}$ aqueous distillate of sage leaves (named sage water).

The sage water was prepared by distillation of a mixture of plant and water ( $1 \mathrm{~kg}$ of fresh sage leaves with $4 \mathrm{~L}$ of distilled water). The distillate ( $2 \mathrm{~L}$ of sage water with $\mathrm{pH}$ 4.02) was kept 40 days until reached $\mathrm{pH} 3.5$. At this point, the sage water was ready to use to obtain macerate $\mathrm{S} 2$.

For metals concentration determination by AAS, 0.5 of pow der of dry leaves of sage have been mineralized with 5 $\mathrm{mL}$ nitric acid and $40 \mathrm{~mL}$ deionized water to $120^{\circ} \mathrm{C}$ for 130 minutes, filtered in $50 \mathrm{~mL}$ volumetric flasks and filled up with water.

\section{Identification and quantification of phenolic compounds by HPLC-DAD}

The resulted extractive solutions were analysed by an adapted USP30 HPLC method [21] used for separation, identification and quantification of the phenolic compounds as previously described [14-16,19].

For separation it was used a Zorbax Eclipse XDB-C18 column: $250 \mathrm{~mm}, 4.6 \mathrm{~mm}$; $5 \mu \mathrm{m}$ (Agilent Technologies). The gradient of elution was phosphoric acid $0.1 \%$ in water (solvent A) and acetonitrile (solvent B) as presented in Table 1.

\begin{tabular}{|c|c|c|}
\hline Time & Solvent A, & Solvent B, \\
(min.) & $\%$ & $\%$ \\
\hline $0-13$ & 90 & 10 \\
\hline 13 & 78 & 22 \\
\hline 14 & 60 & 40 \\
\hline 17 & 60 & 40 \\
\hline 17.5 & 90 & 10 \\
\hline 22 & 90 & 10 \\
\hline
\end{tabular}

Table 1

THE GRADIENT OF ELUTION SOLVENTS
The operation parameters of chromatographic process were: the flow rate - $1.5 \mathrm{~mL} / \mathrm{min}$; the injection volume - 20 $\mu \mathrm{L}$; the analysis time - 22 minutes.

The quantification of founded compounds was performed at $310 \mathrm{~nm}$ and $35^{\circ} \mathrm{C}$. The retention times and DAD spectra were compared to available authentic standards.

To register the retention time of standard, a mixture of standard solutions in $70 \%$ methanol having the following concentrations it was used: $\mathrm{E}$ - resveratrol $=37 \mathrm{mg} / \mathrm{mL}, Z$ - resveratrol $=0.22 \mathrm{mg} / \mathrm{L}$, caffeic acid $=0.36 \mathrm{mg} / \mathrm{mL}$, chlorogenic acid $=0.37 \mathrm{mg} / \mathrm{mL}$, cinnamic acid $=0.58$ $\mathrm{mg} / \mathrm{mL}$, vanillin $=0.42 \mathrm{mg} / \mathrm{mL}$, gallic acid $=0.39 \mathrm{mg} / \mathrm{mL}$, ferulic acid $=0.48 \mathrm{mg} / \mathrm{mL}$, 3-methylgalic acid $=0.34 \mathrm{mg} /$ $\mathrm{mL}$, ellagic acid $=0.43 \mathrm{mg} / \mathrm{mL}$, $p$-coumaric acid $=0.51$ $\mathrm{mg} / \mathrm{mL}$ (Table 2). Standard deviations of retentions time were obtained after statistical processing of the 6 injections (soft SPSS 10). The retention times were between $0.990 \pm 0.025$ min for gallic acid and $15.867 \pm 0.007$ minutes for cinnamic acid.

Identification and quantitative determination of the active constituents from samples macerates was done by comparing the chromatogram of standards mixture.

Table 2

THE RETENTION TIME OF STANDARDS

\begin{tabular}{|c|c|}
\hline Standards & Retention time $\pm \mathrm{SD}$, minutes \\
\hline gallic acid & $0.990 \pm 0.025$ \\
\hline 3-o-methylgallic acid & $2.606 \pm 0.008$ \\
\hline chlorogenic acid & $3.501 \pm 0.015$ \\
\hline caffeic acid & $4.598=0.036$ \\
\hline vanillin & $6.919=0.051$ \\
\hline$p$-coumaric acid & $7.187 \pm 0.019$ \\
\hline ferulic acid & $8.565 \pm 0.058$ \\
\hline$E$-resveratrol & $14.467 \pm 0.017$ \\
\hline ellagic acid & $15.303 \pm 0.027$ \\
\hline$Z$-resveratrol & $15.751=0.058$ \\
\hline cinnamic acid & $15.867 \pm 0.007$ \\
\hline
\end{tabular}




\section{Total phenolic content (TPC)}

The total phenols were estimated according to the FolinCiocalteau method [22- 28].

The absorbance of the coloured phosphowolframate phosphomolibdate complex was measured at $681 \mathrm{~nm}$. Total phenols content of sage leaves macerate was expressed as mg of gallic acid equivalents per 100 grams of dry weight (mg GAE/100g d.w). All samples were performed in triplicate and the mean value was reported.

\section{Calibration curve}

In a series of $50 \mathrm{~mL}$ volumetric flasks volumes of $1 \mathrm{~mL}$, $2 \mathrm{~mL}, 3 \mathrm{~mL}, 4 \mathrm{~mL}, 5 \mathrm{~mL}, 6 \mathrm{~mL}$ and $7 \mathrm{~mL}$ of gallic acid standard solution were introduced and after was added 1 $\mathrm{mL}$ of Folin-Ciocalteau-reagent $1: 10(\mathrm{~V}: \mathrm{V})$ and $1 \mathrm{~mL}$ of $20 \%$ $(\mathrm{w} / \mathrm{v})$ aqueous $\mathrm{Na}_{2} \mathrm{CO}_{3}$; after 10 min the volume was brought to mark with distilled water. After another $30 \mathrm{~min}$. of incubation at $25^{\circ} \mathrm{C}$ the absorbance was measured at $681 \mathrm{~nm}$.

The calibration curve was linear in the range of 0.68 $4.76 \mathrm{mg} \mathrm{GAE} / \mathrm{L},\left(\mathrm{R}^{2}=0.9987\right.$ ) (Figure 1 ).

The characteristics of the obtained calibration curve are: $Y=A+B^{*} X ; A=0.1071 ; B=0.0465$; Correlation coefficient $=0.9987$.

For TPC analysis, $10 \mathrm{~mL}$ of each macerate were transferred into a $25 \mathrm{~mL}$ volumetric flask and brought to the mark with the same solvent previously used for maceration operation.

To measure the total phenols content, $1 \mathrm{~mL}$ of previously diluted samples were added in $25 \mathrm{~mL}$ calibrated flasks each, then $1 \mathrm{~mL}$ Folin-Ciocalteau reagent $1: 2(\mathrm{~V}: \mathrm{V}), 1 \mathrm{~mL}$ sodium carbonate solution $20 \%$ and the process was the same like those used for calibration (Table 5).

\section{DPPH Radical Scavenging test}

The process was the same like those used for calibration. The antioxidant capacity was evaluated using DPPH Radical Scavenging test. Gallic acid (GA) was used as standard to plot calibration curves and the results were expressed as equivalents (mg GAE) [14, 16, 27-32]. In 25 $\mathrm{mL}$ calibrated flasks different volume of gallic acid solutions were added, then $5 \mathrm{~mL}$ DPPH $0.063 \%(1.268 \mathrm{mM})$ in methanol, filled up to the mark with methanol and let in the dark, to the room temperature for 45 minutes before the absorbance registration at $530 \mathrm{~nm}$ versus methanol. Previously, the DPPH solution spectrum was recorded and the maximum absorbance was registered at $530 \mathrm{~nm}$. The solutions absorbance' decrease due to the antioxidant capacity of standard compounds determined the downward allure of calibration curves.

The calibration curve with gallic acid as standard was linear in $0.68-4.08 \mathrm{mg} \mathrm{GAE} / \mathrm{L}$ range and the correlation coefficient was 0.9988 .

To measure the antioxidant capacity, $1 \mathrm{~mL}$ of each sample were added in $25 \mathrm{~mL}$ calibrated flasks, then $5 \mathrm{~mL}$ DPPH $1.268 \mathrm{mM}$ in methanol, filled up to the mark with methanol and let in the dark, to the room temperature for 45 minutes before the absorbance registration at $530 \mathrm{~nm}$ using methanol as blank.
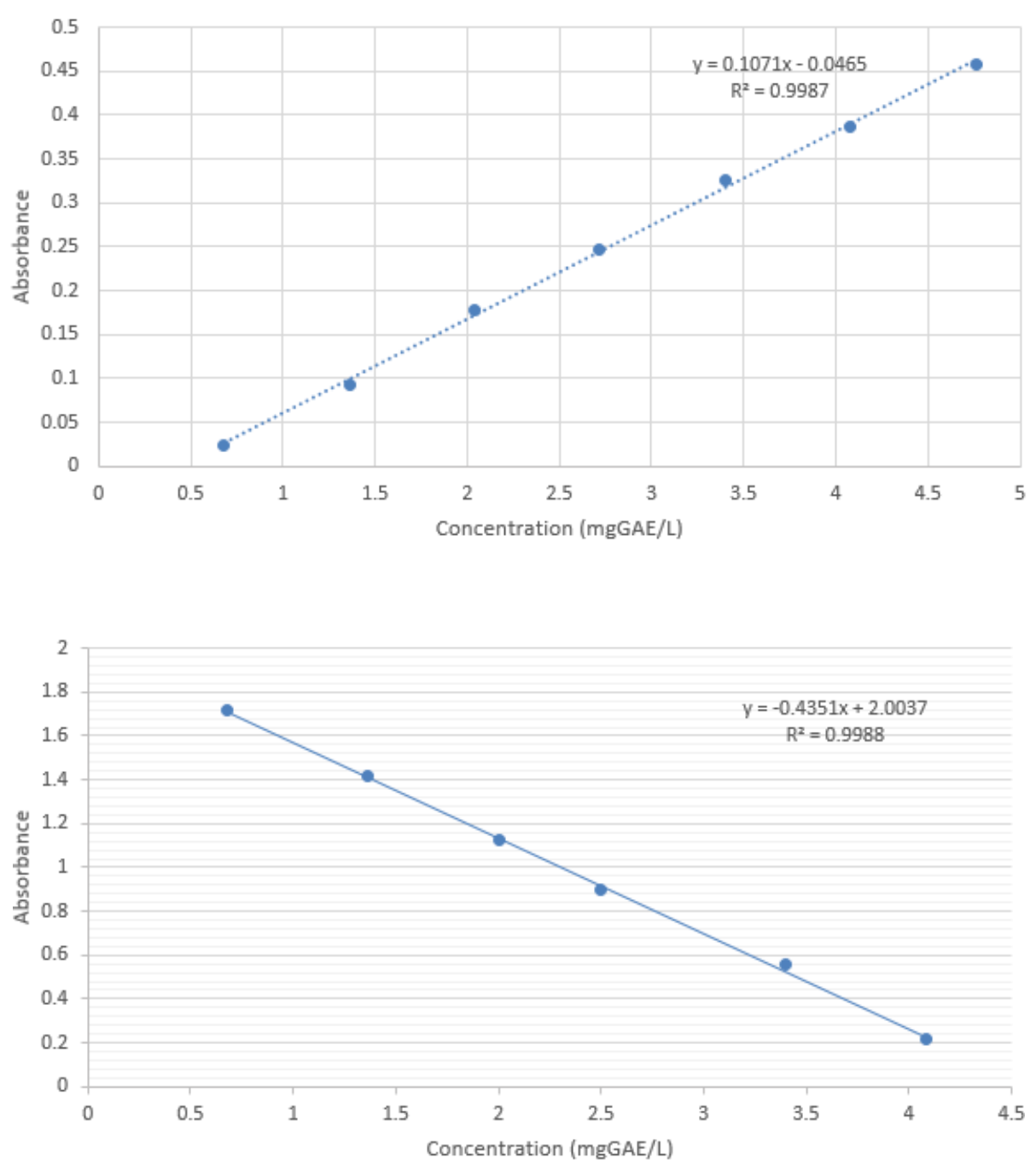

Fig.1. Calibration curve of galic acid in the range of $0.68-4.76 \mathrm{mg}$ $\mathrm{GAE} / \mathrm{L}$ at $681 \mathrm{~nm}$
Fig.2. CALIBRATION CURVE OF GALLIC ACID IN THE RANGE OF 0.68 - $4.08 \mathrm{mg} \mathrm{GAE} / \mathrm{L}$ at $530 \mathrm{~nm}$. 


\begin{tabular}{|l|l|l|l|l|}
\hline Metal & $\begin{array}{l}\text { Concentration domain } \\
(\mathrm{mg} / \mathrm{L})\end{array}$ & $\mathrm{R}^{2}$ & $\begin{array}{l}\text { LOD } \\
(\mathrm{mg} / \mathrm{L})\end{array}$ & $\begin{array}{l}\text { LOQ } \\
(\mathrm{mg} / \mathrm{L})\end{array}$ \\
\hline Cadmium & $0.050-1.000$ & 0.9955 & 0.0610 & 0.0693 \\
\hline Calcium & $40.00-200.00$ & 0.9995 & 4.7400 & 20.140 \\
\hline Copper & $0.050-2.000$ & 0.9994 & 0.0426 & 0.0586 \\
\hline Iron & $0.050-2.000$ & 0.9929 & 0.5084 & 0.1183 \\
\hline Lead & $0.200-8.000$ & 0.9986 & 0.1375 & 1.0280 \\
\hline Magnesium & $1.000-5.000$ & 0.9978 & 2.1040 & 15.130 \\
\hline Manganese & $0.050-2.000$ & 0.9939 & 0.4704 & 0.0597 \\
\hline Nickel & $0.100-4.000$ & 0.9910 & 0.3425 & 0.1051 \\
\hline Potassium & $1.000-5.000$ & 0.9971 & 3.3390 & 29.350 \\
\hline Sodium & $5.000-25.000$ & 0.9966 & 1.2410 & 4.7120 \\
\hline Zinc & $0.050-1.000$ & 0.9941 & 0.0423 & 0.1076 \\
\hline
\end{tabular}

Table 3

PERFORMANCE PARAMETERS FOR AAS MEASUREMENTS
Atomic absorption measurements for metal concentrations

Atomic absorption measurements for metal concentrations were done with a spectrometer ContrAA ${ }^{\circledR}$ 700 using flame technique. The instrument setting and operational conditions were conducted in accordance with the manufacturers' specifications. Therefore, a Certipure multielement standard solution from Merck $(1 \mathrm{mg} / \mathrm{mL}$ of each metal) was used for calibration. The following performance parameters have been determined: concentration domain $(\mu \mathrm{g} / \mathrm{L})$ and correlation coefficients of the calibration curve $\left(R^{2}\right)$, limits of detection (LOD), limits of quantitation (LOQ) (Table 3) [33-36].

\section{Difusimetric evaluation of sage macerates (S1 and S2) activity}

Twenty bacterial strains, both Gram positive and Gram negative (Table 4), were tested against two hydro-alcoholic macerates (S1, S2).

Table 4

BACTERIAL STRAINS USED TO ASSESS THE EFFECT OF SAGE $\operatorname{MACERATES}(\mathrm{S} 1, \mathrm{~S} 2)$

\begin{tabular}{|l|l|}
\hline Bacterial strain & Observations \\
\hline Escherichia coli & Isolated from urinary tract infection (UTI) \\
\hline Klebsiella & Isolated UTI \\
\hline Proteus & Isolated UTI \\
\hline Enterococcus 1 & Isolated UTI \\
\hline Enterococcus 2 & Isolated UTI \\
\hline Enterococcus 3 & Isolated UTI \\
\hline Enterococcus 4 & Isolated UTI \\
\hline Staphylococcus 1 & Isolated from skin infection (SI) \\
\hline Staphylococcus 2 & Isolated (SI) \\
\hline Staphylococcus 3 & Isolated (SI) \\
\hline Staphylococcus 4 & Isolated (SI) \\
\hline Staphylococcus 5 & Isolated (SI) \\
\hline Staphylococcus 6 & Coagulase positive \\
\hline Staphylococcus 7 & Hemolytic, isolated from UTI \\
\hline Staphylococcus 8 & hemolytic, isolated from UTI \\
\hline Staphylococcus 9 & hemolytic, isolated from UTI \\
\hline Staphylococcus 10 & Coagulase negative \\
\hline Staphylococcus 11 & Coagulase negative \\
\hline Staphylococcus 12 & hemolytic, isolated from UTI \\
\hline Staphylococcus 13 & hemolytic, isolated from UTI \\
\hline
\end{tabular}

The evaluation of inhibitory activity of macerates of sage was performed by the well plate method [37]. Bacterial strains were inoculated into Mueller Hinton broth and incubated overnight at $37^{\circ} \mathrm{C}$ for 18 hours. After dilution, the inoculation was carried out by spreading the culture (with density between $9 \times 10^{5}$ and $1 \times 10^{6} \mathrm{UFC} / \mathrm{mL}$ ) with a pharyngeal swab onto Mueller Hinton agar surface. After inoculation, the media were kept for $1 \mathrm{~h}$ to room temperature to allow the surface to dry. Subsequently, wells $(\mathrm{d}=6 \mathrm{~mm})$ were performed using a sterile test tube. 100 $\mu L$ of each macerate were pipetted into wells and media were left at room temperature to allow the diffusion of macerates. Inoculated media were thereafter incubated at $37^{\circ} \mathrm{C}$ for $48 \mathrm{~h}$. The inhibitory effect was assessed as the size of inhibition zone $(\mathrm{mm})$.

\section{Results and discussions}

Phenolic compounds separation, identification and quantification

From all the available authentic standard used for used for determinations, only six individual phenolic compounds it were found in both sage macerates (S1, S2) (Table 5).

The total phenols values indicate that sage macerate S2 has a higher content of phenols compared to sage macerate S1.

Cinnamic acid was found in high concentration for the both analysed macerates, buthigher in macerate S2 (Table 5). Cinnamic acid is an organic acid occurring naturally in plants that has low toxicity and a broad spectrum of biological activities such as: antibacterial, antiviral and antifungal properties [4].

S2 macerate had a higher concentration of gallic acid than S1. Gallic acid has been reported to have therapeutic activities in gastrointestinal, neuropsychological, metabolic and cardiovascular disorders [6].

For the tested sage macerates we notice that chlorogenic acid, ferulic acid and $p$-coumaric acid have variable concentration depending of the particularly properties of these individual phenolic compounds and maceration process.

Therefore, in sage macerate $\mathrm{S} 2$ it was found that phenolic compounds decrease order is: cinnamic acid > gallic acid

\begin{tabular}{|l|c|c|c|c|}
\hline \multirow{2}{*}{ Phenolic compound } & \multicolumn{2}{|c|}{ S1 } & \multicolumn{2}{c|}{ S2 } \\
\cline { 2 - 5 } & $\mathrm{mg} / 100 \mathrm{~g} \mathrm{d.w.}$ & wt $\%$ & $\begin{array}{c}\mathrm{mg} / 100 \mathrm{~g} \\
\text { d.w. }\end{array}$ & wt $\%$ \\
\hline Chlorogenic acid & 5.067 & 0.789 & 18.810 & 2.153 \\
\hline Caffeic acid & 64.023 & 9.976 & 15.858 & 1.816 \\
\hline Gallic acid & 69.357 & 10.808 & 165.893 & 18.991 \\
\hline Cinnamic acid & 473.381 & 73.765 & 652.478 & 74.693 \\
\hline Ferulic Acid & 12.340 & 1.923 & 14.535 & 1.663 \\
\hline p-Coumaric acid & 17.582 & 2.739 & 5.979 & 0.684 \\
\hline Total phenols & 641.750 & 100 & 873.553 & 100 \\
\hline
\end{tabular}

Table 5

CONTENTS (mg/100g d.w.) AND WEIGHT PERCENTAGES (WT\%) OF INDIVIDUAL PHENOLIC COMPOUNDS OF TESTED SAGE MACERATES $(\mathrm{S} 1, \mathrm{~S} 2)$ DETERMINED BY HPLC-DAD 
$>$ chlorogenic acid $>$ caffeic acid $>$ ferulic acid $>p$ coumaric acid and in case of sage macerate S1 the decrease order is: cinnamic acid $>$ gallic acid $>$ caffeic acid $>$ p-coumaric acid acid $>$ ferulic acid $>$ chlorogenic acid.

It was reported that chlorogenic acid has cardioprotective effects and anti-diabetic properties for human health, ferulic acid has anti-aging and skin benefits, caffeic acids has anti-cancer and anti-inflammatory effects and $p$-coumaric acid is recognized to have neuroprotective, antidiabetic and antihyperlipidemic properties [4]

The result indicates a high antioxidant activity of all individual phenolic compounds for the tested sage macerates.

\section{Total phenolic content (TPC)}

The obtained values in case of TPC analysis indicates that Salvia officinalis $L$ leaves have a high amount of phenolic compounds comparable to other literature data $[4,6,8,11]$.

Table 6

THE WEIGHT PERCENTAGES (\%) OF TOTAL POLYPHENOLS AND OF MAJOR PHENOLIC COMPOUNDS DETERMINED IN SAGE SAMPLES

\begin{tabular}{|l|l|c|}
\hline No. & Sample & $\begin{array}{l}\text { TPC } \\
\text { mg GAE/100g d.w. }\end{array}$ \\
\hline 1 & S1 & 1280 \\
\hline 2 & S2 & 1425 \\
\hline
\end{tabular}

The results for TPC indicates that Salvia officinalis $L$ macerate S2, presents a higher amount of phenolic compounds than macerate S1, due to the different solvent used in maceration process.

The difference between the values of phenolic compounds determined by HPLC-DAD and TPC in case of tested sage macerates (S1 and S2) is due to the presence of other phenolic acids that were not determined in the applied HPLC-DAD conditions.

\section{DPPH Radical Scavenging test}

Results of free radical scavenging activity of both sage macerates are given in Table 7.

Table 7

THE ANTIOXIDANT ACTIVITY OF SALVIA OFFICINALISL MACERATES

\begin{tabular}{|l|l|c|}
\hline No. & Sample & $\begin{array}{c}\text { DPPH } \\
\text { mg GAE } / 100 \text { g d.w. }\end{array}$ \\
\hline 1 & S1 & 400 \\
\hline 2 & S2 & 439.5 \\
\hline
\end{tabular}

Data in the table show that the DPPH scavenging activities increase with the amount of the phenolic content found in studied samples.

The results indicate that both samples have significantly antioxidant activities and the differences are given by the particularly of each sage macerate which in case of sage macerate S2 is higher comparing to sage macerate S1. The findings were in agreement with the previous results of phenolic compounds quantification and identification.
Atomic absorption measurements formetal concentrations

Plants can accumulate heavy metals, which can be harmful to the human body or may cause serious health problems for humans $[4,5]$. Therefore, the metal concentrations determinations for consumption plants are an important issue in order to secure the quality of both human and animal life.

The metals concentrations in the studied plant material are presented in Table 8.

\begin{tabular}{|c|c|c|}
\hline No. & Metal & $\begin{array}{c}\text { Concentration } \\
\text { (mg/kg d.w.) }\end{array}$ \\
\hline 1. & $\mathrm{~K}$ & 12980 \\
\hline 2. & $\mathrm{Ca}$ & 10680 \\
\hline 3. & $\mathrm{Mg}$ & 7005 \\
\hline 4. & $\mathrm{Na}$ & 75.66 \\
\hline 5. & $\mathrm{Fe}$ & 478.40 \\
\hline 6. & $\mathrm{Mn}$ & 59.45 \\
\hline 7. & $\mathrm{Cd}$ & $<\mathrm{DL}$ \\
\hline 8. & $\mathrm{Cu}$ & 0.06 \\
\hline 9. & $\mathrm{~Pb}$ & $<\mathrm{DL}$ \\
\hline 10. & $\mathrm{Ni}$ & $<\mathrm{DL}$ \\
\hline 11. & $\mathrm{Zn}$ & 21.75 \\
\hline
\end{tabular}

Table 8

METALS CONCENTRATION (mg/kg d.w.) IN SAGE LEAVESSAMPLE
From all metals considered for analysis, the concentrations of three metals ( $\mathrm{Cd}, \mathrm{Ni}$ and $\mathrm{Pb}$ ) were found below the detection limit, that means there are not toxic metals in the studied sage samples. Except copper and zinc, all others found minerals are in considerable amount; this is normal given their role in living organisms.

Potassium and calcium are essential microelements for all higher plants and they were found in relatively large quantities in sage leaves.

Potassium, calcium, magnesium and sodium play specific important roles for plants and human body and the results indicate that sage leaves are noticeable source of these essential microelements.

Based on the obtained results, the metal concentration from sage leaves expressed in $\mathrm{mg} / 100 \mathrm{~g}$ d.w. are in the range of permissible limit [33-36] and decrease in the order: $\mathrm{K}>\mathrm{Ca}>\mathrm{Mg}>\mathrm{Fe}>\mathrm{Na}>\mathrm{Mn}>\mathrm{Zn}>\mathrm{Cu}$.

\section{Difusimetric evaluation of sage macerates activity}

Generally, all strains were more or less sensitive to both macerates of sage (Table 9). However, the extent to which the individual bacteria responded to macerates was variable. In this respect, there was also a significant difference of the ability of macerates to inhibit Gram positive and Gram negative bacteria. The effect of macerates was generally weaker on Gram negative bacteria compared to Gram positive. In the case of Gram negative bacteria, the most pronounced inhibitory effect had macerate S1 (4 mm) compare to the effect was observed in case of $\mathrm{S} 2$ macerate $(3.66 \mathrm{~mm})$. Enterococcus strains proved to be the most sensitive, illustrated by the growth inhibition area between 9.25 (S1) and $5.5 \mathrm{~mm}$ for S2. Our results were comparable to other findings showing significant inhibitory effect of sage components on enterococci [37]. 


\begin{tabular}{|c|c|c|}
\hline \multirow{2}{*}{$\begin{array}{l}\text { Bacterial strain } \\
\text { macerate }\end{array}$} & \multicolumn{2}{|c|}{$\begin{array}{l}\text { Inhibition } \\
\text { zone (mm) }\end{array}$} \\
\hline & S1 & $\mathrm{S} 2$ \\
\hline Escherichia coli & 4 & 4 \\
\hline Klebsiella & 3 & 3 \\
\hline Proteus & 5 & 4 \\
\hline Average activity & 4 & 3.66 \\
\hline Enterococcus I & 10 & 5 \\
\hline Enterococcus 2 & 10 & 5 \\
\hline Enterococcus 3 & 5 & 6 \\
\hline Enterococcus 4 & 12 & 6 \\
\hline Average activity & 9.25 & 5.5 \\
\hline Staphylococcus I & 10 & 4 \\
\hline Staphylococcus 2 & 10 & 10 \\
\hline Staphylococcus 3 & 4 & 4 \\
\hline Staphylococcus 4 & 7 & 6 \\
\hline Staphylococcus 5 & 10 & 5 \\
\hline Staphylococcus 6 & 10 & 4 \\
\hline Staphylococcus 7 & 6 & 4 \\
\hline Staphylococcus 8 & 10 & 7 \\
\hline Staphylococcus 9 & 8 & 6 \\
\hline Staphylococcus 10 & 10 & 8 \\
\hline Staphylococcus $\Pi$ & 9 & 5 \\
\hline Staphylococcus 12 & 8 & 5 \\
\hline Staphylococcus 13 & 10 & 7 \\
\hline Average activity & 8.61 & 5.76 \\
\hline Overall activity & 7.28 & 4.97 \\
\hline
\end{tabular}

Enterococci can cause a range of infectious diseases (urinary tract infections, bacteraemia, endocarditis), and they are regarded as opportunistic pathogens in the hospital environment [38]. Therefore, sage components might be view as valuable alternatives to antibiotics against especially vancomycin resistant strains [39]. Important effects of growth inhibition were also recorded in Staphylococcus strains, when large inhibition zones were recorded, ranging from $5.76 \mathrm{~mm}$ (S2) to $8.61 \mathrm{~mm}(\mathrm{~S} 1)$. Significant effects of sage have also been observed against Staphylococcus aureus in other studies [40-48]. Importantly, the sage components were efficient against methicillin resistant strains of $S$. aureus that cause difficult to treat infections [40-46]. A higher sensitivity of Enterococcus and Staphylococcus groups was also recorded by others [37,44], findings more or less similar to our results. Overall, the mean value of inhibition zone was the higher in case of S1 and decreased in case of S2 macerate.

\section{Conclusions}

Our results showed that the total phenols concentration in sage macerates (S1 and S2) estimated by FolinCiocâlteau method is as following: the sage macerate S2 contains a higher amount of phenolic compounds than S1.

The difference between the values of total phenolic compounds determined by HPLC-DAD and TPC is linked to the presence of other phenolic acids that were not determined in the applied HPLC-DAD conditions.
The antioxidant capacity determined by DPPH indicates that for both samples is significantly high and the differences can be attributed to the maceration procedure.

The metal concentration from sage leaves expressed in $\mathrm{mg} / 100 \mathrm{~g} \mathrm{d.w}$. are in the range of permissible limit and decrease in order: $\mathrm{K}>\mathrm{Ca}>\mathrm{Mg}>\mathrm{Fe}>\mathrm{Na}>\mathrm{Mn}>\mathrm{Zn}>\mathrm{Cu}$.

Sage macerates exhibite variable inhibitory effect on the bacterial growth depending on the macerate type and bacterial species. Most sensitive groups were Enterococcus and Staphylococcus while the growth of Gram negative bacteria was less affected by both macerates.

\section{References}

1. RAJABIA, Z., EBRAHIMIA, M., FARAJPOURA, M., MIRZAC, M., RAMSHINI, H., Ind. Crop. Prod., 61, 2014, p. 233.

2. ADAMS, M., GMUNDER, F., HAMBURGER, M., J. Ethnopharmacol., 113, 2007, p. 363.

3. GARCIA, C., MENTI, C.F., LAMBERT, A., THIAGO, B., MOURA, S., CALLONI, C., BRANCO, C.S., SALVADOR, M., ROESCH-ELY, M., HENRIQUES, J.A.P., Ann. Braz. Acad. Sci., 88, no. 1, 2016, p. 282.

4. KHIYA, Z., HAYANI, M., GAMAR, A., KHARCHOUF, S., AMINE, S., BERREKHIS, F., BOUZOUBAE, A., ZAIR, T., EL HILALI, F., Journal of King Saud University - Science, 31, 2019, p. 322.

5.GHORBANI, A., ESMAEILIZADEH, M., Journal of Traditional and Complementary Medicine, 7, 2017, p. 433.

6. RODRIGUES, M.R.A., KANAZAWA, L.K.S., NEVES, T.L.M.H. DAS, SILVA, C.F.DA., HORST, H., PIZZOLATTI, M.G., SANTOS, A.R.S., BAGGIO, C.H., WERNER, M.F.D.P., J. Ethnopharmacol., 139, 2012, p.519.

7. OANCEA, I. A., STANCIU, T., BARBU, A., VLAD, A., J ournal of Science and Arts, 1, 38, 2017, p. 113.

8.STANCIU, T.I., CRISTACHE, N., TCACI, C., TANASESCU, I., MATIS, C., Proceedings of the $11^{\text {th }}$ International, Management Conference: The Role of Management in the Economic Paradigm of the XXI ${ }^{\text {st }}$ Century (IMC 2017), Book Series: International Management Conference, Bucharest, Romania, 2017, p. 429.

9. HARVEY, A.L., Drug Discovery Today, 13, 2008, p. 894

10. VELICKOVIC, D.T., RANCELOVIC, N.V., RISTIC, M.S., VELICKOVIC, A.S., SMELCEROVIC, A.A., J.Serb.Chem.Soc., 68, no. 1, 2003, p. 17.

11.STANCIU, G., CRISTACHE, N., LUPSOR, S., DOBRINAS, S., Rev. Chim. (Bucharest), 68, no. 7, 2017, p. 1429.

12.MAYER, B., BAGGIO, C.H., FREITAS, C.S., DOS SANTOS, A.C., TWARDOWSCHY, A., HORST, H., PIZZOLATTI, M.G., MICKE, G.A., HELLER, M., DOS SANTOS, E.P., OTUKI, M.F., MARQUES, M.C.A., Fitoterapia, 80, 2009, p. 421.

13.KADHIM, S.M., MOHAMMED, M.T., AHMED, O.M., MOHAMMED, A., JASSIMAND, N., Int. J. Chem. Sci., 14, no. 2, 2016, p. 711.

14. STANCIU, G., AONOFRIESEI, F., LUPSOR, S., POPESCU, A., SIRBU, R., Rev.Chim.(Bucharest), 70, no. 5, 2019, p. 1800.

15.STANCIU, G., AONOFRIESEI, F., CRISTACHE, N., LUPSOR, S., Rev. Chim.(Bucharest), 68, no.8, 2017, p. 1752.

16.STANCIU, G., OANCEA A.I., OANCEA, E., CHIRILA, E., Rev. Chim.(Bucharest), 70, no. 3, 2019, p. 749.

17.STANCIU, G., LUPSOR, S., NATO Security through Science Series C: Enviromental Security, Chemicals as International and Accidental Global Enviromental Threats, Ed. Springer, Borovetz, Bulgaria, 2005, p. 451-454.

18.LUPSOR, S., STANCIU, G., EPURE, D., CHIRILA, E., NATO Science of Peace and Security Series C - Environmental Security, Exposure and Risk Assessment of Chemical Pollution - Contemporary Methodology, Ed. Springer, Bulgaria, 2009, p. 434 - 437.

19.STANCIU, G., LUPSOR, S., POPESCU, A., OANCEA, A.I., J ournal of Science and Arts, 1, no. 38, 2017, p. 107.

20.STANCIU, G., SAVA, C., SURDU, O., SECRIERU, D., ARCUSI, M., LUPSOR, S., Scientific Study\&Research", VII, no. 3, 2006, p. 535. 21.*** NF 25, United States Pharmacopeia and the National Formulary (USP 30/NF 25), Rockville (MD), The United States Pharmacopeial Convention Inc., 914, 2007. 
22.DOBRINAS, S., STANCIU, G., LUPSOR, S., Journal of Science and Arts, 2, no. 38, 2017, p. 321.

23.SIRBU, R. STANCIU, G., TOMESCU, A., CADAR, E., Rev. Chim.(Bucharest), 70, no. 4, 2019, p. 1197.

24.POPOV, I. N., LEWIN, G., Photosintesitized chemiluminiscence. Its medical and industrial applications for antioxidizability tests. In: A. M. Garcia-Campana, WRG Baeyens (Eds) Chemiluminiscence in Analytical Chemistry, Marcel Decker Inc., New York, Bassel. 2001.

25.STANCIU, G., LUPSOR, S., SIRBU, R., J ournal of Science and Arts, 1, no. 38, 2017, p. 141.

26.STANCIU, G., MIHAIESI, M., S. LUPSOR, S., Scientific Study \& Research, VII, no. 4, 2006, p. 799.

27.STANCIU, G., ROTARIU, R., POPESCU, A., TOMESCU, A., Rev.Chim.(Bucharest), 70, no. 4, 2019, p. 1173.

28.STANCIU, G., LUPSOR, S., TOMESCU, A., SIRBU, R., Rev.Chim.(Bucharest), 70, no. 2, 2019, p. 373.

29.SIRBU, R., MUSTAFA, A., TOMESCU, A., STANCIU, G., CADAR, E., Mat. Plast., 56, no. 1, 2019, p. 148.

30.SIRBU, R., STANCIU, G., CADAR, E., TOMESCU, A., CHERIM, M., Rev.Chim.(Bucharest), 70, no. 3, 2019, p. 835.

31.CHERIM, M., SIRBU, R., TOMESCU, A., POPA M.F., CADAR, E., Mat. Plast., 56, no. 1, 2019, p. 179.

32.NICOLESCU, C.M., BUMBAC, M., OLTEANU, R.L., ALECU, G.C., BOBOACA-MIHAESCU, D.N., NECULA, C., RADULESCU, C., J ournal of Science and Arts, 46, no.1, 2019, p. 201.

33.*** urnalul oficial al Uniunii Europene, Reg. CE 1881/2006, 58, no. 3,2006, p. 3.
34.***J urnalul oficial al Uniunii Europene, Dir. 2002/46/CE, 36, no. 13, 2002, p. 39.

35.*** urnalul oficial al Uniunii Europene, Reg. CE 161/2011, L 296, 2011, p. 29-30.

$36 . * * *$ J urnalul oficial al Uniunii Europene, Dir. CE 46/2002, 58, no. 3, 2006, p. 3.

37.COWEN, M.M., Clin. Microbiol. Rev., 12, no. 4, 1999, p. 564.

38.MAATHUIS F.J.M., J. Exp. Bot., 65, no. 3, 2014, p.849.

39.EL ASTAL, Z.Y., ASHOUR, A., KERRIT, A.A.M., Pak. J. Med. Sci., 21, 2, 2005, p. 187.

40.ELIOPOULOS, G.M., GOLD, H.S., Clin. Infect. Dis., 33, 2001, p. 210. 41.ZOMORODIAN, K., MOEIN, M., PAKSHIR, K., KARAMI, F., SABAHI, $Z$. , J ournal of Evidence-Based Complementary $\&$ Alternative Medicine, 22, no. 4, 2017, p. 770.

42.ARORA, D., KAUR, J., Intern J Antimicrob Agents, 12, 1999, p. 257. 43.OKEMO, P., MWATHA, W., CHHABRA, S., FABRY, W., Afr. J. Sci. Tech., 2, 2001, p. 113.

44.MADAMOMBE, I., AFOLAYAN, A., Pharmaceut. Biol., 41, 2003, p. 199.

45.INOUYE, S., TAKIZAWA, T., YAMAGUCHI, H., J Antimicrob Chemother., 47, 2001, p. 565.

46.NITTA T, ARAI T, TAKAMATSU H, INATOMI, Y., MURATA, H., IINUMA, M.,TANAKA, T., ITO, T., ASAI, F. IBRAHIM, I., NAKANISHI, T., WATABE, K., J Health SCi., 48, 2002, p. 273.

47.GORDON, R.J., LOWY, F.D., Clin Infect Dis., 46, 2008, p. S350. 48.BAJ PAI, V.K., RAHMAN, A., KANG, S. C., Int. J. Food Microbiol., 125, no. 2, 2008, p. 117.

$\overline{\text { Manuscript received:4.11.2019 }}$ 